\title{
PERAN SEO DALAM MENINGKATKAN RELIABILITAS PEMASARAN PRODUK VIA MEDIA ONLINE PADA FORUM MUSLIMAH DEPOK
}

\author{
Ahmad Maulana Irfanudin, Didi Sunardi, Ratna Sari, Imbron, Nariah \\ Program Studi Manajemen \\ Universitas Pamulang \\ Email: dosen01868@unpam.ac.id
}

\begin{abstract}
The purpose of Community Service Activities (PKM) is to carry out one of the three obligations of the Tri Dharma Perguruan Tinggi. In addition, it is expected that by serving the community, the existence of higher education institutions can contribute to the development and application of knowledge to the community. The method of activity used is to visit the Forum Muslimah Depok, Al-Awwal Mosque, addressed on Jalan Mawar Raya, Depok Jaya and look for problems that are in place so as to provide the right solution in motivating members who has business or UMKM in Depok, West Java, especially for Jama'ah Masjid Al Awwal Masjid Depok Jaya and gave training there on 01-03 October 2019. This training aims to develop the ability to increase marketing through online media with SEO methods and techniques (Search Engine Optimization) for Muslimah Forum members, AlAwwal Mosque, Depok Jaya. The results of community service activities (PKM) obtained indicate that prior to the implementation of PKM, Depok Muslimah Forum members did not yet know the terms related to product marketing via online media, but after the implementation of activities known members of the Depok Muslimah Forum could understand the basics of content creation with simple SEO rules. PKM activities play a positive role in increasing the knowledge and skills of participants in creating SEO-based content The knowledge gained in Community Service this time is expected to be able to provide enthusiasm especially for the lecturers and other academicians of the University of Pamulang in providing material counseling, motivation and contributing to the public in and outside the campus environment of the University of Pamulang
\end{abstract}

Keywords: Content, Search Engine Optimization, Online

\section{Abstrak}

Tujuan dari Kegiatan Pengabdian Kepada Masyarakat adalah untuk melaksanakan satu dari tiga kewajiban Tri Dharma Perguruan Tinggi. Selain 
itu diharapkan dengan pengabdian kepada masyarakat, keberadaan perguruan tinggi dapat memberikan kontribusi kepada pengembangan dan penerapan keilmuan kepada masyarakat. Metode kegiatan yang digunakan adalah dengan mengunjungi Forum Muslimah Depok, Masjid Al-Awwal, beralamat di Jalan Mawar Raya, Depok Jaya dan mencari pemasalahan yang ada di tempat tersebut sehingga dapat memberikan solusi yang tepat dalam memotivasi anggota yang adalah pelaku bisnis di Depok Jawa Barat khususnya Jamaah Masjid Al Awwal Depok Jaya dan akan memberikan pelatihan disana pada tanggal 01-03 Oktober 2019. Pelatihan ini bertujuan agar mengembangkan kemampuan untuk meningkatkan pemasaran lewat media daring (online) dengan metode dan teknik SEO (Search Engine Optimization) bagi para anggota Forum Muslimah, Masjid Al-Awwal, Depok Jaya. Hasil kegiatan pengabdian masyarakat yang diperoleh menunjukkan bahwa sebelum pelaksanaan PKM, para anggota Forum Muslimah Depok belum mengenal istilah-istilah terkait dengan pemasaran produk lewat media daring (online), namun setelah pelaksaan kegiatan diketahui para anggota Forum Muslimah Depok dapat memahami dasar-dasar pembuatan konten dengan kaidah SEO sederhana. Kegiatan PKM berperan positif dalam meningkatkan pengetahuan dan keterampilan peserta dalam pembuatan konten berbasis SEO. Ilmu yang diperoleh pada Pengabdian Masyarakat kali ini diharapkan mampu memberikan semangat khususnya bagi para dosen maupun civitas akademika Universitas Pamulang lainnya dalam memberikan penyuluhan materi, motivasi serta berkontribusi bagi khalayak masyarakat di dalam maupun luar lingkungan kampus Universitas Pamulang

Kata Kunci: Konten, Search Engine Optimization, Daring

\section{A. PENDAHULUAN}

Pengertian SEO menurut Rand Fishkin, dikutip dalam weebly (2015) adalah kombinasi dari taktik dan strategi yang mencakup tetapi tidak dibatasi oleh optimalisasi informasi, kemudahan penggunaan, fokus pada konten, penargetan audiens, desain, pengembangan situs, penelitian keyword, penempatan keyword, link building, social media marketing dan segala macam elemen marketing online maupun offline yang mendukung tujuan untuk menerima lebih banyak traffik dari mesin pencari. Forum Muslimah Depok, salah satu forum yang mewadahi kaum ibu sekaligus jamaah Majelis ta'lim Masjid Al-Awwal Depok Jaya. Menurut Huges dan Kapoor, "Bisnis itu sendiri adalah kegiatan individu yang mana terorganisis, atau bisa dikatakan terorganisasi oleh serangkaian individu untuk menghasilkan suatu produk atau barang untuk dijual, serta menjual barang maupun jasa yang ditujukan 
guna untuk mendapatkan keuntungan dan disamping itu ditujukan guna untuk memenuhi kebutuhan dari masyarakat".

Setiap anggota aktif di Forum Muslimah Depok memiliki industri rumahan yang memproduksi berbagai macam jenis produk, mulai dari produk makanan hingga souvenir yang kualitasnya tidak kalah dari produk sejenis di pasaran. Cara mereka memasarkan produk pun mulai dari menjajakan barang dari rumah ke rumah sampai dengan memasarkan lewat jejaring media sosial seperti facebook, dan instagram. Menurut Rudjito (2003), UMKM adalah usaha yang punya peranan penting dalam perekonomian negara Indonesia, baik dari sisi lapangan kerja yang tercipta maupun dari sisi jumlah usahanya. UMKM sendiri telah diatur berdasarkan UU No. 20 tahun 2008 tentang Usaha Mikro Kecil dan Menengah (UMKM). Untuk mendukung tercapainya sasaran diatas, Kami para dosen prodi manajemen ingin membekali pemahaman dan memberikan gambaran mengenai teknik SEO dalam penjualan secara daring (online) kepada Forum Muslimah Depok yang berfokus pada peningkatan jumlah traffic pengunjung ke halaman (page) penjualan online.

\section{B. METODE PELAKSANAAN KEGIATAN}

Metode kegiatan yang digunakan adalah dengan mengunjungi Forum Muslimah Depok, Masjid Al-Awwal, beralamat di Jalan Mawar Raya, Depok Jaya dan mencari pemasalahan yang ada di tempat tersebut sehingga dapat memberikan solusi yang tepat dalam memotivasi anggota yang adalah pelaku bisnis di Depok Jawa Barat khususnya Jamaah Masjid Al Awwal Depok Jaya, dan memberikan pelatihan disana pada tanggal 01 sampai dengan 03 Oktober 2019. Pelatihan ini bertujuan agar para anggota Forum Muslimah Depok, khususnya pelaku sekaligus pemilik usaha mikro kecil dan menengah agar dapat meningkatkan kualitas diri melalui transfer ilmu teori sekaligus praktik ini.

Sebelum dilaksanakannya kegiatan pengabdian kepada masyarakat di Forum Muslimah Depok, Masjid Al-Awwal, beralamat di Jalan Mawar Raya, Depok Jaya, anggota tim yang berjumlah 5 orang dosen melakukan beberapa tahapan, melalui pra survei ke lokasi untuk berkoordinasi dengan Kepala LPM Kelurahan Depok Jaya, Bp. Yudi Yanto, M.T. dan Ketua Forum Muslimah Depok, Ibu Dr. Maslihati Nur, SH. MH. Serta perijinan melaksanakan acara pengabdian, selanjutnya tim membuat penjadwalan kegiatan selama 3 (tiga) hari dengan berkoordinasi termasuk pembuatan materi untuk dapat disampaikan serta diaplikasikan oleh para anggota forum, sampai dengan pembuatan laporan kegiatan pengabdian kepada masyarakat dan pengajuan keluaran dari kegiatan pengabdian masyarkat berupa jurnal PKM.

\section{HASIL DAN PEMBAHASAN}

Pelaksanaan kegiatan Pengabdian Kepada Masyarakat oleh Lembaga Penelitian dan Pengabdian Masyarakat (LPPM) Universitas Pamulang yang dilakukan oleh dosen-dosen program studi Manajemen telah berjalan dengan lancar dan mendapat sambutan positif dari tempat pelaksanaan kegiatan ini yaitu anggota Forum Muslimah Depok, Masjid Al-Awwal, beralamat di Jalan Mawar Raya, Depok Jaya.

Harapan kami dengan pengabdian ini dapat membuka wawasan para anggota Forum Muslimah Depok, Masjid Al-Awwal, Depok Jaya serta mengaplikasikannya dalam kegiatan 
usaha industri rumahan, usaha kecil dan menengah. Materi yang kami berikan yaitu pembelajaran secara teori dan praktek dalam bidang manajemen khususnya terkait pembuatan konten SEO dalam pemasaran produk melalui media daring.

Dalam laporan kegiatan ini mungkin banyak kekurangan yang ada, untuk itu kami berharap masukan dan kritikan dalam rangka perbaikan untuk kegiatan-kegiatan pengabdian masyarakat dimasa yang akan datang. Semoga kegiatan pengabdian masyarakat ini dapat bermanfaat bagi masyarakat sekitar lingkungan Universitas Pamulang dan khususnya Forum Muslimah Depok, Masjid Al-Awwal, beralamat di Jalan Mawar Raya, Depok Jaya.

\section{KESIMPULAN DAN SARAN}

Dari hasil kegiatan pengabdian kepada masyarakat di Forum Muslimah Depok, Masjid Al-Awwal, beralamat di Jalan Mawar Raya, Depok Jaya yang dilaksanakan selama kurun waktu 3 (tiga) hari dapat meningkatkan kualitas diri mereka berdasarkan materi yang disampaikan, untuk meningkatkan penjualan produk maupun jasa dalam sektor usaha kecil sekalipun. Dan juga masih perlunya melakukan pendidikan dan pelatihan pemasaran lewat media daring (online) agar terbuka lebih banyak potensi pendapatan pasar melalui media tersebut. Untuk meningkatkan kualitas konten atau deskripsi produk dalam pemasarannya, adalah penting untuk memahami metode-metode standar SEO agar dapat berkompetisi dengan usaha-usaha lain yang sejenis yang jumlahnya tidak sedikit.

Setelah kegiatan pengabdian kepada masyarakat ini berakhir baik dari pelatihan dan pendampingan diharapkan para anggota Forum Muslimah Depok, Masjid Al-Awwal, beralamat di Jalan Mawar Raya, Depok Jaya Khususnya para pelaku usaha kecil dan menengah agar dapat meningkatkan kualitas diri mereka untuk terus berkompetisi dalam merebut pasar atau konsumen. Untuk meningkatkan kualitas sumber daya manusia yaitu dengan diadakan penyesuaian dalam menempatkan sumber daya manusia sesuai bidang pengetahuan dan keterampilannya. Selanjutnya diperlukan pengawasan dan pengendalian yang memadai untuk dapat mengontrol sumber daya manusia dalam bersikap agar dapat menangani kendala dalam integritasi dan komunikasi. Sehingga kami sebagai tim pengabdi dari Universitas Pamulang Fakultas Ekonomi akan terus melakukan kegiatan serupa dan terkelanjutan serta berkesinambungan untuk membangun bangsa ini menjadi lebih baik.

\section{DAFTAR PUSTAKA}

Ilham, M. (2018). Apa itu SEO? Pengertian, Konsep Dasar, dan Manfaatnya. Diakses 10 Oktober 2019 10.00 WIB. https://www.niagahoster.co.id/blog/apa-itu-seo/

Ina, P. (2009). Menggerakkan Sektor Riil UKM dan Industri. Bandung: J.Ravianto.1985

Irfanudin, Ahmad Maulana. et al. (2019). Jurnal Pengabdian Dharma Laksana. Vol.2 No.1.

Kotler, P., \& Armstrong, G. (2008). Prinsip-prinsip Pemasaran. Edisi. 12. Jilid 1. Jakarta: Erlangga.

Rudjito (2003). Strategi Pengembangan Umkm Berbasis Strategi Bisnis, Makalah yang disampaikan pada Seminar Peran Perbankan Dalam Memperkokoh Ketahanan Nasional Kerjasama Lemhanas RI dengan BRI 
Solihin, D. (2020), Faktor-Faktor Yang Mempengaruhi Kinerja Pemasaran Pada PT Prima Ufuk Semesta (Studi Empiris Pada Outlet Rekanan Pt. Prima Ufuk Semesta Di Wilayah Jabodetabek), Jurnal Semarak, Vol. 3. No. 1.

Solihin, D. (2020), Pengaruh Kualitas Pelayanan, Harga, Dan Promosi Terhadap Keputusan Pelanggan Dalam Memilih Klub Basket Satria Indonesia Tangerang Selatan, Jurnal Pemasaran Kompetitif, Vol. 3, No. 3.

Sukidjo. (2004). Strategi Pemberdayaan Usaha Mikro, Kecil dan Menengah. Jurnal Ekonomi dan Pendidikan, vol. 2, No. 1.

Tambunan, T. (2002). Usaha Kecil dan Menengah di Indonesia: Beberapa Isu Penting. Jakarta: Salemba Empat. 